\title{
The Multiplier Effects of Waste Management in RT-07 of Guntung Village, In Bontang, East Kalimantan, Indonesia.
}

\author{
Sri Djuwani Ekowati ${ }^{*}$, Sudharto P Hadi ${ }^{1}$. Dwi P Sasongko ${ }^{2}$ \\ ${ }^{1}$ Graduate Program in Environmental Sciences, Diponegoro University, Semarang-Indonesia \\ ${ }^{2}$ Departement of Physics, Faculty of Science and Mathematics, Diponegoro University
}

\begin{abstract}
In 2010, Neighborhood area 07 in Guntung Village received Black Award from Bontang government due to environmental issues. The issues are included the mounting trash resulted from this area which is not managed well, dirty and slum environment, unpleasant odors from the rubbish heap and scabies suffered by residents. As the company located next to Guntung Village, PT. Pupuk Kalimantan Timur (PKT) is very concerned about environmental problems. It encouraged these residents to initiate establishing Groups through Corporate Social Responsibility. It aims to "change the slum area to be healthy and great". This program is established to solve the waste problem and exploring economic opportunities. Mekarsari Group turns leaves into compost and its development innovates by processing food waste into liquid organic fertilizer (Indonesia called POC). To improve the group's institutional status, the joint venture group Mekarsari formed and in extending process its competitiveness, change to Mekarsari Cooperative, this paper observes a legal status. The research method is qualitative with participative observation and technique of data collection employed with interviews. The changing waste into compost and POC, have various effects on sustainable development. The slum village changed to green village. The residents receive additional income and reducing Greenhouse Gases.
\end{abstract}

Keywords: Black Award, Green Village, Greenhouse Gases

\footnotetext{
* Corresponding author:sekowati@pupukkaltim.com
} 


\section{Introduction}

Guntung village, located in North Bontang Sub-district, Bontang, East Kalimantan, Indonesia, consists of 24 Rukun Tetangga (the acronym is RT or neighborhood). RT-07 is the closest area to Pupuk Kalimantan Timur (PKT) plant operations, which produces urea fertilizer, NPK, and biological fertilizers such as Biotara fertilizer specifically for swamps. On the $11^{\text {th }}$ Anniversary of Bontang in October 2010, RT-07 of Guntung village received Black Award from Bontang City government related to cleanliness competition between Neighborhoods in Bontang. The award given as a slum and dirty village due to environmental problems related to poor waste management is certainly not a compliment but it is a satire that made the residents is ashamed. The poorly managed mounting trash, the ignorance from the residents towards garbage and surrounding environment create negative impacts to the residents. It is such as air pollution in the form of unpleasant odors from landfill, and the spread of germs such as scabies suffered by the residents, makes RT07 receives a negative image as a slum and dirty village [1].

PKT conducts development in RT-07 as one of its buffer zone areas through Corporate Social Responsibility (CSR) program. With the residents of RT-07 who are determined to "Change the Slum Village into a Healthy and Green Village" (abbreviated as MEKARSARI), PKT forms a Joint Venture Group (Indonesia called KUB) in the community Empowerment Program. The members of Mekarsari group are mostly RT- 07 Dasawisma (the smallest unit of PKK or Family Welfare Guidance Program) members. PKT cooperated with the local Government officer namely Guntung Village officers and Bontang Health Agency especially Community Health Center (Puskesmas) of Lhoktuan in handling the environmental problems in RT-07, for implementing the Clean and Healthy Living Style (PHBS). The jointly designed program is a waste management and treatment program for scabies problems until the residents are free from scabies [2].

Specifically for waste management, RT-07 residents are given trainings by PKT on sorting organic and inorganic waste and their processings thus the waste in RT 07 can be handled properly to create a clean and healthy environment. The result of sorting performed by residents namely inorganic waste such as plastic bottles, cans and boxes are sent to Bontang Landfill, which is managed by Bontang Environment Agency [3]. Whereas organic waste such as leaves trash from plants, is processed by residents into compost. The main raw material for making compost is leaves trash that is obtained by residents from the results of sweeping their yards and the surrounding RT environment. Apart from leaves trash that is processed into compost, RT-07 residents also innovate in processing organic food waste from each household collected, then it is processed into Liquid Organic Fertilizer (POC). The compost and POC from RT-07 residents resulted from the waste management are used as the fertilizer for decorative plants and vegetables in RT-07 residents' yards and the rest is sold to the surrounding community and companies. With the increase of Mekarsari group members, the production of compost and POC produced also increases. It needs broader market access therefore; the institution of Mekarsari group is strengthened to become a legal entity cooperative [1].

A cooperative is a business organization or a business entity which its existence equals to other business organizations in the market. With the increasingly open and integrated global economic market, cooperatives must be able to compete as well as companies in general. This activity can only be performed if the cooperative is able to carry out the business principles as it should be. A cooperative will not last long if it only has a comparative excellence but it should have a competitive excellence or competitiveness as the main requirement to enter a market. The key words in order to achieve competitive excellence in managing a cooperative are effective and efficient [4]. 
In terms of composting, [5] explained that the basic principles in composting is to reduce the comparison between the carbohydrate and nitrogen $(\mathrm{C} / \mathrm{N}$ ratio) of organics materials to be equal with the comparison between carbohydrate and nitrogen $(\mathrm{C} / \mathrm{N}$ ratio $)$ of soil around $(10-12)<20$. Therefore, the organics material is equally the same with the surrounding soil $\mathrm{C} / \mathrm{N}$ ratio therefore the organic materials, which already became compost, can be absorbed by plants. Some changes may occur as the results of composting, namely: carbohydrate, cellulose, hemicellulose, fat and candle became $\mathrm{CO}_{2}$ and water; egg whites become ammonia, $\mathrm{CO}_{2}$ and water; decomposition of organic compounds into compounds that can be absorbed by plants. These changes will reduce the amount of carbon and increase the nitrogen level hence the value of $\mathrm{C} / \mathrm{N}$ ratio will be lower and stabile, close to the score of $\mathrm{C} / \mathrm{N}$ soil ratio.

Compost is the result of fermentation or decomposition of organic materials such as plants, animals, or other organics waste. Some of the beneficial properties of compost are: improving the structure of clay soil to become light, improving the binding capacity of sandy soil that the soil does not scatter, increasing the water holding capacity of soil, improve drainage and air conditioning in soil. By enhancing the binding capacity of soil against nutrients, containing complete nutrients even though in small amounts, helping the weathering process of minerals, providing the availability of food for microbes, reducing the activity of harmful microorganisms [5].

Explained that 1 ton of organic trash is generates $2.85 \mathrm{~kg}$ of methane gas $\left(\mathrm{CH}_{4}\right)$ [6]. Methane gas contributes to Greenhouse Effect, which causes about 21 times greater effect than $\mathrm{CO}_{2}$. Greenhouse Effect contributes to global climate change.

\section{Research Method}

The research method is qualitative with participative observation and technique of data collection employed with interviews, involving the Chairman of RT-07 Mekarsari Group of Guntung village and PKT CSR Staff as the informant [7]

\section{Results and Discussion}

From the results of the writer's participative observations and interviews, the waste management in RT-07 performed by Mekarsari group produces positive impacts with multiplier effect which fulfills the concept of sustainable development based on $3 \mathrm{P}$ namely Planet, People and Profit $[8,9]$.

\subsection{Planet}

The view of Planet is related to the nature of residents who are environmentally friendly. The residents of RT-07 in Guntung village are responsive to the dirty and slum environment, so that they processed organic trash into compost and Liquid Organic Fertilizer (POC). The process of making compost is started with collecting leaves trash and household waste. The leaves trash is obtained from several sources, namely from the leaves swept in the residents' own yards and from the head office of PKT's yard, and from other RT deposits, which are purchased at IDR. 200 per $\mathrm{kg}$ while the household compost is obtained from the food, remains of RT-07 residents themselves. For 4 years (2017-2020) Mekarsari group has processed 101 tons of garbage, produced 50 tons of compost, and 4.993 liters of Liquid Organic Fertilizer (POC). When the density of organic and household wastes are considered the same as canteen with density $=0.173 \mathrm{~kg} /$ liter and landfill waste at 
the height of the Final Disposal (Indonesia called TPA) as high as 30 meters, Mekarsari Cooperation has a role in reducing landfill area for the trash pile of $19.59 \mathrm{~m}^{2}$ [10]. Then Mekarsari Cooperative contributed to reducing GHG emissions by $6045 \mathrm{~kg} \mathrm{CO}_{2}$ eq [6].

The process of making POC is very simple. The ingredients are $1 \mathrm{~kg}$ of household waste (wet garbage) mixed with 2 packages of fermented food yeast each of 10 grams, 1 packet of shrimp paste of 10 grams, 100 grams of brown sugar, $500 \mathrm{ml}$ of rice washing water, and $500 \mathrm{ml}$ of coconut water, and 4 liters of well water.

Stir the mixture and allow it for fermentation for 14 days to generate 5 liters of POC. The coconut water used by Mekarsari Group is obtained from the waste of coconut sellers in the nearest market with RT-07 while $1 \mathrm{~kg}$ compost fertilizer needs $2 \mathrm{~kg}$ of dry leaves and $1 \mathrm{~kg}$ of 10 percent POC solution. Which is sprayed evenly to the waste and the mixture is let to rest for 2 until 3 days, then the compost is ready to be harvested. If the compost will be used as one of the ingredients of organic fertilizer, the next step is chopping the compost with compost chopping machine to make it more refined and easily mixed with other ingredients. The scheme of making compost and POC is described in Figure 1. The compost resulted is sold as well as used as fertilizer for decorative and vegetable plants in RT-07 residents' area, making the surrounding area green and beautiful. The residents of RT-07 that are frequently appointed to represent Guntung village in green village and waste management competitions in Bontang, provincial, and even national level and won the competitions. Within 4 years (2015 until 2019) Mekarsari Cooperative won 8 awards from various competitions at the city, East Kalimantan province, and national levels [1, 3, 8].

\subsection{People}

The view of People Mekarsari cooperative give job opportunity, income generation, improvement of capability in managing the group, improvement of social cohesion housewife (Indonesia called dasawisma ) RT-07. To improve the capacity/competence in managing organic trash from dasawisma RT-07 members in Guntung village, PKT provided several in-house trainings in Bontang or outside East Kalimantan Province. The trainings given among others were good composting procedures, basic administration for bookkeeping, trainings on introduction to bacterials for fertilizer, trainings on introduction to soil structure and trainings on introduction to the plants with high economic values. The group implements the knowledge gained from the trainings as shown in pioneering demonstration plot for testing compost. The group also performs several benchmarking such as cooperation institutional, nurseries and care of organic plants. Before the program is finished, PKT assists the Group in managing quality control, administration and marketing fields so the product quality is maintained and the products are well salable [1].

In terms of institutional development, in the second year of PKT assistance, Mekarsari group became a Joint Business Group (KUB) and in the sixth year after the exit program, Mekarsari KUB became a legal entity, namely Mekarsari Cooperative to expand product marketing and to increase competitiveness. From the Health side, the residents of RT-07 have implemented the clean and healthy living style (Indonesia called PHBS) in their environment, thus they no longer suffer from scabies, which they previously suffered from.

In terms of confidence, the self-confidence from the management and members of Mekarsari Cooperative increases, because the government of Bontang has appointedd them as the resource in producing organic fertilizer in other villages and sub-districts in Bontang. On a national scale event, in December 2018, Mekarsari Cooperative was invited for sharing knowledge during the national level Gold and Green Proper award ceremony held by the Ministry of Environment and Forestry (Indonesia called KLHK). 
In terms of social cohesion, it is increasing among local residents to communicate closely with each other in carrying out composting and POC processing, as well as the surrounding village and district officials, company personnel and the Bontang city government. In addition to the above, guests of Bontang City Government, Pupuk Indonesia Subsidiary (Anper PI) and other companies to conduct comparative studies [1].

According to the social aspect of the growth of Mekarsari cooperative members increased from 2017 there are 23 members, in 2018 there were 23 members, in 2019 there were 24 members and in early 2020 there were 30 members.

\subsection{Profit}

Mekarsari Cooperative has processed organic trash into compost and POC from 2017 to 2020 as much as 101 tons leaves trash and household waste. From the waste production results, 50 tons of compost and 4,993 liters of Organic Liquid Fertilizer (POC) are produced with a selling value of IDR. 64,973,000. The selling result is distributed to all members according to each of their role so can they have additional income for their family. For the marketing, the compost product is sold to community as well as to companies, especially PKT. With its status as a legal entity Cooperative, in the eyes of law, Mekarsari has the same position as a company, thus it can make cooperation with a company (MoU). In connection with this matter, Mekarsari Cooperative has made MoU with PKT. Mekarsari Cooperative becomes the supplier of compost which is used as one of raw materials in producing Biotara organic fertilizer for swamps fertilizer produced by PKT $[1]$. 


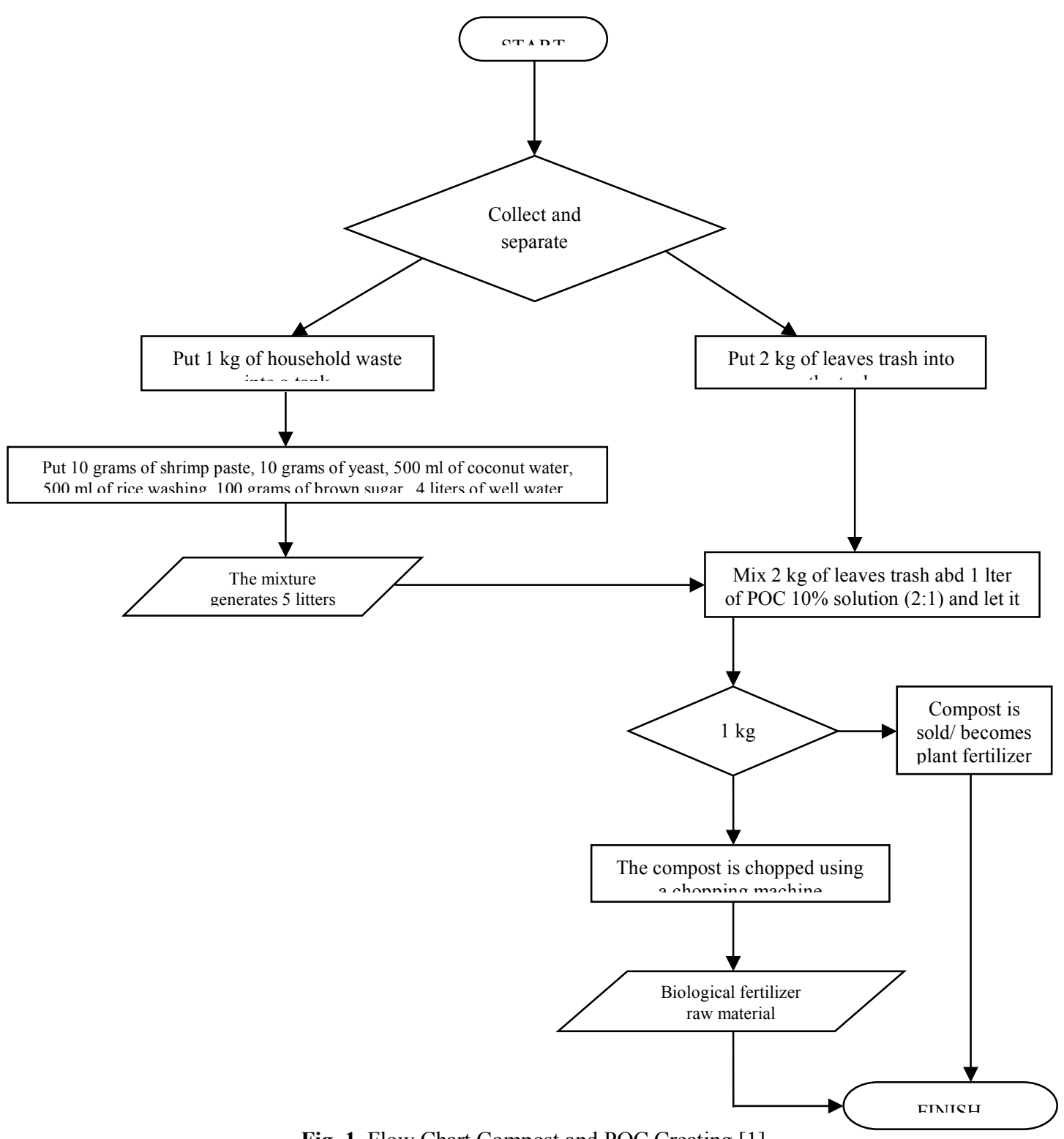

Fig. 1. Flow Chart Compost and POC Creating [1] 


\section{Conclusion}

Through Mekarsari Cooperative from the results of processing trash in the surrounding environment, the residents of RT-07 have experienced positive impacts, which bring multiplier effects in terms of environment, social and economy, namely:

1. RT-07 village, which previously was a dirty and seedy area and received Black Award predicate now become a clean, beautiful village and is called green village, which produce 8 awards from several competitions in city, provincial and national level followed from 2015 until 2019.

2. In processing trash into compost and POC, the members of Housewife (Indonesia called Dasawisma) RT - 07 collaborated in Mekarsari Cooperative receive additional income from the selling of compost and POC.

3. Dasawisma from other neighborhoods also receives additional income from trash and leaves swept from their yard and surrounding, because the leaves trash can be in there can be sold to Mekarsari Group as of Rp 200,- per kg. The selling result can be exchanged with sembako or snacks in groceries belong to Mekarsari Cooperative.

4. The official caretakers of Mekarsari Cooperative become resources of how to process trash to be compost and POC in other villages in Bontang, in other CSR projects assisted by PKT, in the national level knowledge sharing during National Gold Proper Award Event attended by the Minister of Environment or KLHK in Jakarta in December 2018.

5. Mekarsari Cooperative becomes a destination / benchmark from the guests of Bontang City Government, other companies and the subsidiaries (Anper) of Pupuk Indonesia (PI). 


\section{Reference:}

[1] Departemen CSR PKT, "Laporan CSV Mekarsari Binaan PKT," Bontang, (2020)

[2] Broto Sunaryo; Meizar Effendi, Indahnya Berbagi Masyarakat Mandiri : Potret Program Corporate Social Responsibility Pupuk Kaltim. Jakarta: Balai Pustaka, (2020)

[3] Sudharto P.Hadi, Tanggung Jawab Sosial dan Lingkungan Perusahaan. Semarang: Undip Press Semarang, (2019)

[4] M. Azrul Tanjung, Koperasi Dan UMK. Jakarta: Penerbit Buku Erlangga, 2017.

[5] Darma Susetya SP, PANDUAN LENGKAP MEMBUAT PUPUK ORGANIK. Bantul: Pustaka baru Press, (2018)

[6] A. Herlambang, H. Sutanto, and K. Wibowo, "PRODUKSI GAS METANA DARI PENGOLAHAN SAMPAH PERKOTAAN DENGAN SISTEM SEL,” J. Teknol. Lingkung., (2016)

[7] S. P. Hadi, Metodologi Penelitian Lingkungan Bidang Sosial, Cetakan Pe. Semarang: Undip Press Semarang, (2017)

[8] E. Ganis Sukoharsono, "SUSTAINING A SUSTAINABILITY REPORT BY MODIFYING TRIPLE BOTTOM LINE TO PENTAPLE BOTTOM LINE: AN IMAGINARY RESEARCH DIALOGUE,” Int. J. Account. Bus. Soc., (2019)

[9] N. A. Rosyidah, "Analisis Pengungkapan Triple Bottom Line dan Faktor Yang Mempengaruhi," Equity, (2017)

[10] Reni Marsida, "KAJIAN TIMBULAN DAN KOMPOSISI SAMPAH SEBAGAI DASAR PENGELOLAAN SAMPAH DI KAMPUS II UNIVERSITAS

BHAYANGKARA JAKARTA RAYA,” J. Env. Eng. Waste Manag., vol. 2, no. 2, pp. 69-78 (2017) 